Note

\title{
EFFECT OF 6-BA ON NODAL EXPLANT BUD SPROUTINGS OF COFFEA ARABICA CV. MUNDO NOVO (1)
}

\author{
LUIS CARLOS DA SILVA RAMOS ${ }^{(2)}$; JULIETA ANDREA SILVA DE ALMEIDA ${ }^{(3)}$
}

\begin{abstract}
Coffee plants can be micropropagated by nodal bud sprouting using the 6-benzylaminopurine (6BA) hormone. However, literature reports the use of a wide range of $6-\mathrm{BA}$, from 0.5 to $88.8 \mu \mathrm{M} \mathrm{L}^{-1}$. So, this study was performed to narrow that range. Nodal explants of Coffea arabica cv Mundo Novo obtained from in vitro plantlets were inoculated on gelled-MS medium supplemented with different concentrations of 6-BA. Two assays were carried out: in the first one, 6-BA was used at concentrations of $0,5,25,50$, and $100 \mu \mathrm{M} \mathrm{L}^{-1}$, being evaluated at 43 and 123 days. In the second experiment, dosis of 10,20 and $30 \mu \mathrm{M} \mathrm{L}^{-1}$, have evaluated at 65 and 100 days. Treatments with 6-BA induced multiple sprouting from the nodal explants, which were best characterized around 100 days after inoculation. The nodal explants grew taller and showed multiple shoots, whereas the effect of 6-BA at 5 to $25 \mu \mathrm{M} \mathrm{L}^{-1}$ was similar to that with higher concentrations (50 and $100 \mu \mathrm{M} \mathrm{L}^{-1}$ ). Nodal explants yielded from 2.9 to 6.0 buds per node, achieving height of 1.3 to $1.5 \mathrm{~cm}$ at 5 to $25 \mu \mathrm{M} \mathrm{L}^{-1}$ of 6-BA, whereas they yielded from 4.3 to 4.9 buds per node but the sprouting grew about $0.8 \mathrm{~cm}$ at 50 and $100 \mu \mathrm{M} \mathrm{L}^{-1}$ of 6 -BA. This study indicated that multiple sprouting of lateral buds can be induced by lower concentrations of 6-BA, for example, from 10 to $30 \mu \mathrm{M} \mathrm{L} \mathrm{L}^{-1}$, diminishing possible risks of somaclonal variation due to high levels of hormone concentration.
\end{abstract}

Key words: coffee, nodal bud, micropropagation.

\section{RESUMO}

\section{EFEITO DE 6-BA NA BROTAÇÃO DE GEMAS DE EXPLANTES NODAIS DE COFFEA ARABICA CV. MUNDO NOVO}

O cafeeiro pode ser micropropagado via brotação de gemas laterais, aplicando o regulador de crescimento 6-benzilaminopurina (6-BA). Entretanto, a literatura apresenta ampla variação da dose empregada, desde 0.5 a $88.8 \mu \mathrm{M} \mathrm{L}^{-1}$. Assim, este estudo visou otimizar doses para explantes nodais do cafeeiro C. arabica cv Mundo Novo. Explantes nodais, obtidos de plântulas cultivadas in vitro, foram inoculados em meio MS geleificado, com adição de diferentes concentrações de 6-BA. Foram feitos dois experimentos: no primeiro, 6-BA foi usado nas doses de $0,5,10,25,50$ e $100 \mu \mathrm{M} \mathrm{L}^{-1}$ e avaliado aos 43 e 123 dias; no segundo, 10, 20 e $30 \mu \mathrm{M} \mathrm{L}^{-1}$, avaliado aos 65 e 100 dias após a inoculação dos explantes. Os tratamentos com 6-BA induziram a multibrotação dos explantes nodais, e os resultados foram mais bem caracterizados aos cem dias. Os explantes nodais tratados formaram multibrotações que também atingiram maior altura; todavia, o efeito de 6-BA nas concentrações entre 5 a $25 \mu \mathrm{M} \mathrm{L}^{-1}$ foi semelhante ao das doses

$\left({ }^{1}\right)$ Recevied for publication in March 31, 2004 and accepted in February 23, 2005.

( $\left.{ }^{2}\right)$ Centro de Pesquisa e Desenvolvimento de Recursos Genéticos Vegetais, Instituto Agronômico, Caixa Postal 28, 13001-970 Campinas (SP). Brasil. E-mail: lcramos@iac.sp.gov.br

$\left({ }^{3}\right)$ Fellowship Consórcio Brasileiro de Pesquisa e Desenvolvimento do Café. 
mais elevadas, 50 e $100 \mu \mathrm{M} \mathrm{L}^{-1}$. As doses de 5 a $25 \mu \mathrm{M} \mathrm{L}^{-1}$ de 6-BA induziram a brotação de 2,9 a 6,0 gemas por nó, atingindo de 1,3 a $1,5 \mathrm{~cm}$, enquanto os tratamentos de 50 a $100 \mu \mathrm{M} \mathrm{L}^{-1}$ formaram 3,0 a 4,9 gemas por nó e as suas brotações atingiram cerca de $0,8 \mathrm{~cm}$ de altura. Observou-se neste estudo que a multibrotação de explantes nodais de C. arabica cv Mundo Novo pode ser induzida por concentrações menores de 6-BA, entre 10 a $30 \mu \mathrm{M} \mathrm{L}^{-1}$, diminuindo os riscos de variação somaclonal devido às altas concentrações de hormônio.

Palavras-chave: café, gemas nodais, micropropagação.

\section{Introduction}

Coffee is one of the cultivated crops of major economic importance to Brazil. It also has great social significance because of the large amount of labor involved in its cultivation. The main cultivated species in the country is Coffea arabica, which accounts for about $90 \%$ of the planted area.

Micropropagation of coffee trees is not only a means of plant propagation, but also of germoplasm preservation. According to the source of explant, and its subsequent manipulation, the micropropagation may occur via axillary bud proliferation, multiple shoots from hypocotyl segments (NyANGE and McNicol, 1993) and via direct or indirect somatic embryogenesis (Williams and MAHESWARAN, 1986). However, tissue culture can generate somaclonal variation, which could be useful in Coffea, as reported by SONDAHL (2001). This is an exception, rather than a rule, however, since most somaclonal variations are naturally deleterious. Micropropagation through nodal explants is less prone to this variation (GANESH and SREENATH, 1997).
Plant propagation by bud sprouting from nodal explants could be used for commercial production in C. arabica. In this species there are four buds per axil (SondAHL et al., 1985). GouveIA (1987) also reported that there are about four to five buds in the axils of orthotropic and plagiotropic branches of C. arabica and C. canephora. Sprouting of most of these buds is therefore valuable, since it would result in a larger number of plants in the same space and in a shorter term.

Cytokinins have the property of breaking bud dormancy (MoOre, 1979; Turnbull and Hamke, 1985; TAMAs, 1987). Among the cytokinins, 6benzylaminopurine (6-BA) promotes bud sprouting in nodal explants of coffee trees (SoNDAHL et al., 1985). This response has been associated with the use of different concentrations of 6-BA from 0.5 to $88.8 \mu \mathrm{M}$ $\mathrm{L}^{-1}$ (Table 1).

Therefore, considering the 6-BA range from 0.5 to $88.8 \mu \mathrm{M} \mathrm{L}^{-1}$ found in the literature, the aim was to identify adequate concentration of 6-BA to be used in order to obtain a larger number of shoots from nodal explants of Coffea arabica cv Mundo Novo.

Table 1. Literature examples of 6-BA doses for bud sprouting on nodal explants of Coffea

\begin{tabular}{|c|c|c|c|c|}
\hline Genotype & Doses $(\mu \mathrm{M} L-1)$ & NBN & Days* & Reference \\
\hline C. arabica & $0.0,1.8,8.9,44.4$ & $1.0,2.5,2.8$ & 49 & Custer (1980) \\
\hline C. arabica cv Arabusta & $0.0,4.4,22.2,44.4$ & & 90 & Dublin (1980) \\
\hline C. arabica cv Mundo Novo & $0.0,13.3,26.6,39.9$ & 4.3 & 90 & Forni et al. (1994) \\
\hline C. arabica & $0.0,0.4,2.2,4.4,22.2,44.4$ & $1.0,3.1,3.9,5.5$ & 60 & Ganesh \& Sreenath (1977) \\
\hline C. arabica cv Catimor & $0.0,17.8,35.5,44.4,53.3,71.0$ & $4.0,2.5$ & 90 & Garcia \& Rafael (1989) \\
\hline C. arabica cv Caturra Amarelo & $0.0,26.6,39.9,53.3,66.6$ & 1.3 & 120 & Jesus et al. (2002) \\
\hline C. arabica cv Rubi, Catuaí, Icatu & $0.0,26.6,39.9,53.3,66.6$ & $4.3,3.3,3.7$ & 90 & Jesus et al. (2003) \\
\hline C. arabica cv Ruiru 11 & $0.0,2.2,22.2,44.4,66.6,88.8$ & 4.0 & 60 & Kahia (1993) \\
\hline C. arabica cv Mundo Novo & 50.0 & 7.5 & 180 & Nakamura \& Sondahl (1981) \\
\hline $\begin{array}{l}\text { C. arabica cv Caturra Amarelo, } \\
\text { cv Geisha }\end{array}$ & 50.0 & $6.8,2.5,2.7$ & 140 & Ribeiro \& Carneiro (1989) \\
\hline C. arabica & 40.0 & 2.2 & 35 & Sondahl et al. (1985) \\
\hline
\end{tabular}

NBN: Number of buds per node; *Days after inoculation. 


\section{Material and methods}

Nodal explants of Coffea arabica cv. Mundo Novo were obtained from plantlets grown from seeds previously germinated and cultivated in vitro (Figure 1). Each seed was placed in a $50 \mathrm{~mL}$ glass flask with Murashige and Skoog (1962) medium (MS). Each explant consisted of an internode excised from plantlets that were originally about 4.0 to $9.0 \mathrm{~cm}$ tall, raised from the seeds, after twenty months from originally inoculation. The work was carried out in the plant tissue laboratory of the Center of Research and Development of Plant Genetic Resources of the Agronomic Institute, at Campinas, São Paulo.

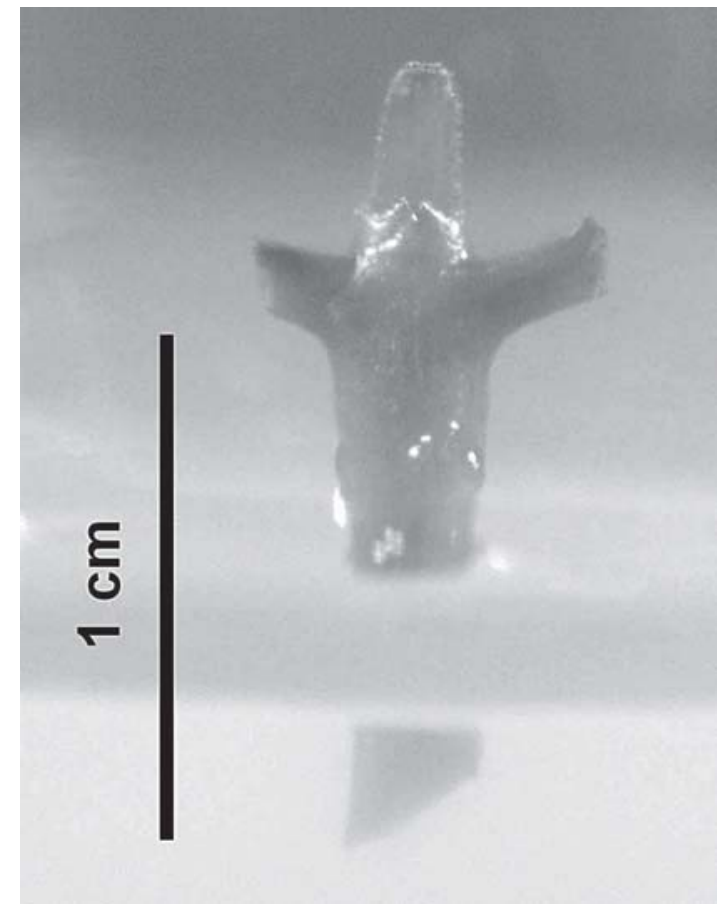

Figure 1. Nodal explant of C. arabica cv Mundo Novo obtained from the seedlings in vitro.

The internodes were placed on gelled MS medium supplemented with cysteine- $\mathrm{HCl}$, inositol, vitamins (nicotinic acid, thiamine and pyridoxine) and sucrose $\left(20 \mathrm{~g} \mathrm{~L}^{-1}\right)$, the $\mathrm{pH}$ was adjusted to 5.6 , and agar added at $6 \mathrm{~g} \mathrm{~L}^{-1}$. Each explant was inoculated in $350 \mathrm{~mL}$ glass flasks with $50 \mathrm{~mL}$ of medium. The cytokinin 6-benzylaminopurine (6-BA - SIGMA) was used to induce sprouting.

Two experiments were carried out: in the first one, 6-BA was used at the concentration of $0,5,10$, 25,50 and $100 \mu \mathrm{M} \mathrm{L}^{-1}$, and in the second one, at the concentration of 10, 20 and $30 \mu \mathrm{M} \mathrm{L}^{-1}$. Each treatment had ten replications, and each nodal explant was kept individually.
The experiments were set up in an entirely randomized design, in a room with 16 hours photoperiod, illuminated by cool white fluorescent lamps of 4,000 lux of light intensity, and temperature of $25^{\circ} \mathrm{C}$.

Treatments were evaluated regarding the number of buds induced by node, and height attained by the shoots, as well. The first experiment was evaluated at 43 and 123 days and the second at 65 and 100 days after the inoculation of the nodal explants.

\section{Results and Discussion}

Most of the treatments with 6-BA induced bud sprouting on nodal explants of Coffea arabica cv. Mundo Novo, producing similar number of shoots per treatment, two on the average. For example, in the first experiment, this was observed in the first evaluation at 43 days after the inoculation of the nodal explants (Figure 2A).

However, in this experiment the number of shoots per nodal explant nearly doubled for all the treatments with 6-BA by the second evaluation at day 123. Although treatments with 5, 10, 25, 50 and 100 $\mu \mathrm{M} \mathrm{L}^{-1}$ of 6-BA induced the largest absolute number of shoots (from 2 to 6 ), results were found to be similar to one another. Loss of nodal explants due to oxidation was also observed, an occurrence quite common to happen (Custers, 1980; Dublin, 1980).

The highest bud sprouting in absolute value (6.0) was observed with 6-BA doses of $25 \mu \mathrm{M} \mathrm{L}^{-1}$ at the 123 day measurement (Figure 2A). In other similar studies, it was verified the effect of 6-BA $26.6 \mu_{\mathrm{M} \mathrm{L}}^{-1}$, which resulted in 4.3 sproutings in nodal explant of C. arabica cv Mundo Novo at 90 days (ForNI et al., 1994); that $17.8 \mu \mathrm{M} \mathrm{L}^{-1}$ induced 4.0 sproutings per nodal explant of $C$. arabica $\mathrm{cv}$ Catimor at 90 days (GARCia and Rafael, 1989) and $26.6 \mu \mathrm{M} \mathrm{L}^{-1}$ with 4.0 sproutings in C. arabica cv Caturra Amarelo at 120 days (Jesus et al., 2002). Conversely, low dose ( $5 \mu \mathrm{M}$ $\left.\mathrm{L}^{-1}\right)$ of 6-BA induced two sprouts per node on average (Figure 2A).

This is also reported on literature; in most cases these low concentrations did not promote a larger number of shoots than higher concentrations; for example, 0.5 and $2.5 \mu \mathrm{M} \mathrm{L}^{-1}$ of 6-BA resulted in the formation of 1.0 to 2.5 shoots per axil, respectively (CUSTERs, 1980); and the concentrations 0.5; 2.2 and $4.4 \mu \mathrm{M} / \mathrm{L}$ resulted in 1, 1 and 3 shoots, too, respectively (GANeSh and SREENATH, 1997). 

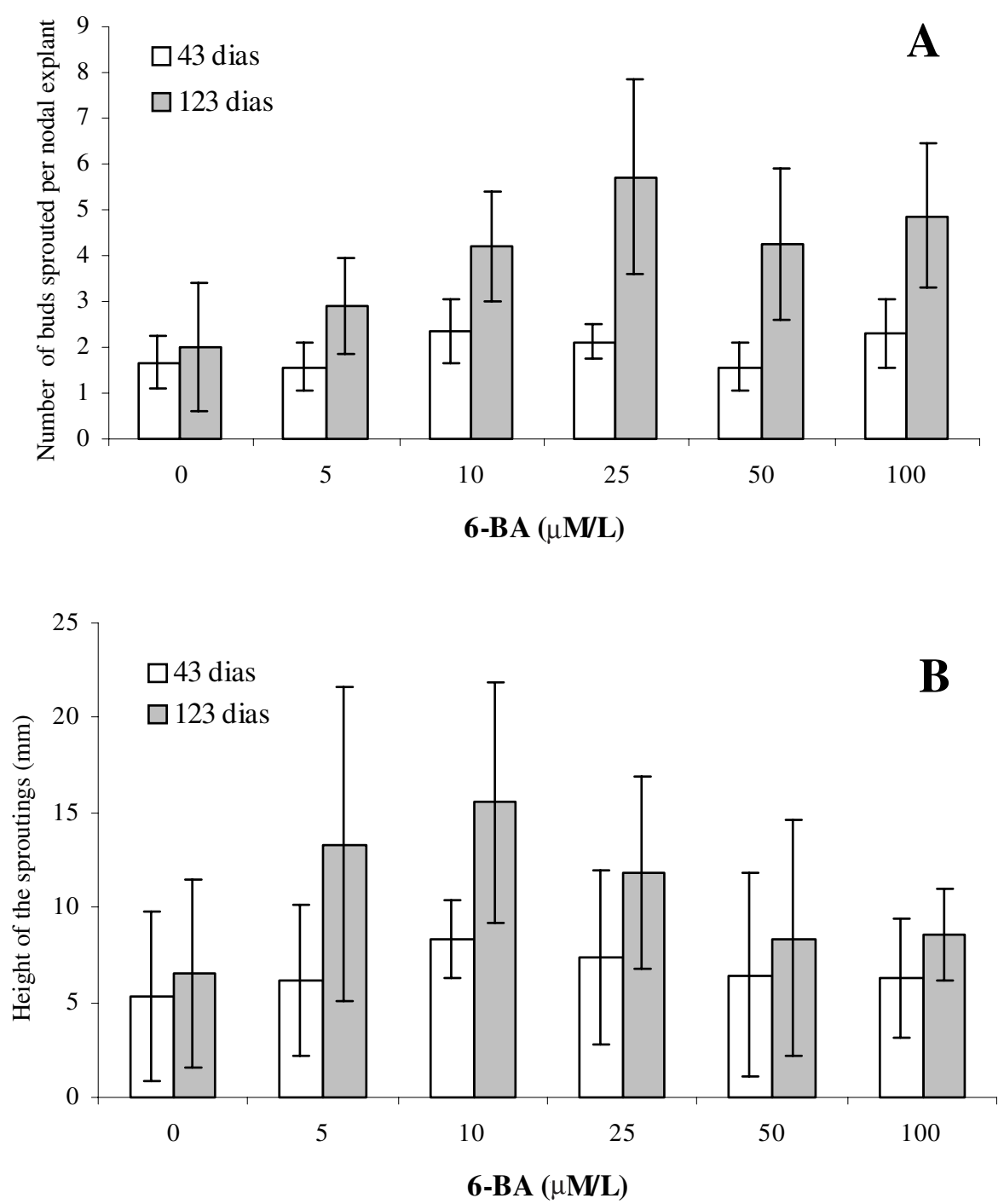

Figure 2. Effect of different concentrations of 6-BA on the number of buds sprouted per nodal explant (A) of C. arabica cv Mundo Novo, and on the height of the sproutings (B) 43 and 123 days after the inoculation. Vertical bars: standard errors.

The results of this study showed that lower concentrations, such as 10 and $25 \mu \mathrm{M} \mathrm{L}^{-1}$ of 6-BA, had a similar effects to that of higher concentrations, 50 and $100 \mu \mathrm{M} \mathrm{L}^{-1}$. The ability of a plant tissue to differentiate is associated with its competence and determination to initiate an event whenever it is exposed to an environmental or internal signal (MacDaniel, 1984). Besides competence and determination, the plant tissue is also sensitive to growth substances, that is, a tissue that is determined may initiate a certain event in response to the presence of a growth substance, either at high or low concentration, depending on its sensitivity (TREWAVAS, 1981). The nodal explants of Mundo Novo were therefore sensitive to 6-BA since they responded to both high and low concentrations.
Besides the number of sproutings, the height was also affected by 6-BA treatments. In the first experiment, the shoots showed no treatment relevant difference in height on day 43 , which was $0.5 \mathrm{~cm}$, on average. However, on day 123, the shoots treated with 5,10 and $25 \mu \mathrm{M} \mathrm{L}^{-1}$ attained $1.3,1.6$ and $1.3 \mathrm{~cm}$ of length in height, respectively, whereas control shoots were $0.7 \mathrm{~cm}$ tall, on average (Figure $2 \mathrm{~B}$ ).

Considering that in the first experiment maximum sprouting occurred with low concentrations of 6-BA (10 and $\left.25 \mu \mathrm{M} \mathrm{L}^{-1}\right)$, a second experiment was carried out to test intermediate concentrations, 10, 20 and $30 \mu \mathrm{M} \mathrm{L}^{-1}$, so as to establish a more limited range. In this second experiment, the number of buds sprouted per explants was similar for all treatments, both on day 65 and 100 (Figure 3A) from the 
beginning of the experiment, 3 and 4 buds, on average, respectively. The lower concentration $\left(10 \mu \mathrm{M} \mathrm{L}^{-1}\right)$ of 6-BA induced a similar number of shoot sprouts to that of higher concentrations, 20 and $30 \mu \mathrm{M} \mathrm{L}^{-1}$, corroborating the result of the first experiment.

As for the height attained by the shoots, similar responses were found also for the three concentrations tested $\left(10,20\right.$ and $\left.30 \mu \mathrm{M} \mathrm{L}^{-1}\right)$ both on day 65 and on day 100 after the beginning of the experiment (Figure 3B). Therefore, experimental data obtained in this study from nodal explants of Coffea arabica cv Mundo Novo by 100 days of culture indicated that multiple sprouting of lateral buds can be induced by using lower concentrations of 6-BA, for example, from 10 to $30 \mu \mathrm{M} \mathrm{L}^{-1}$, than those much higher ones reported in the literature.
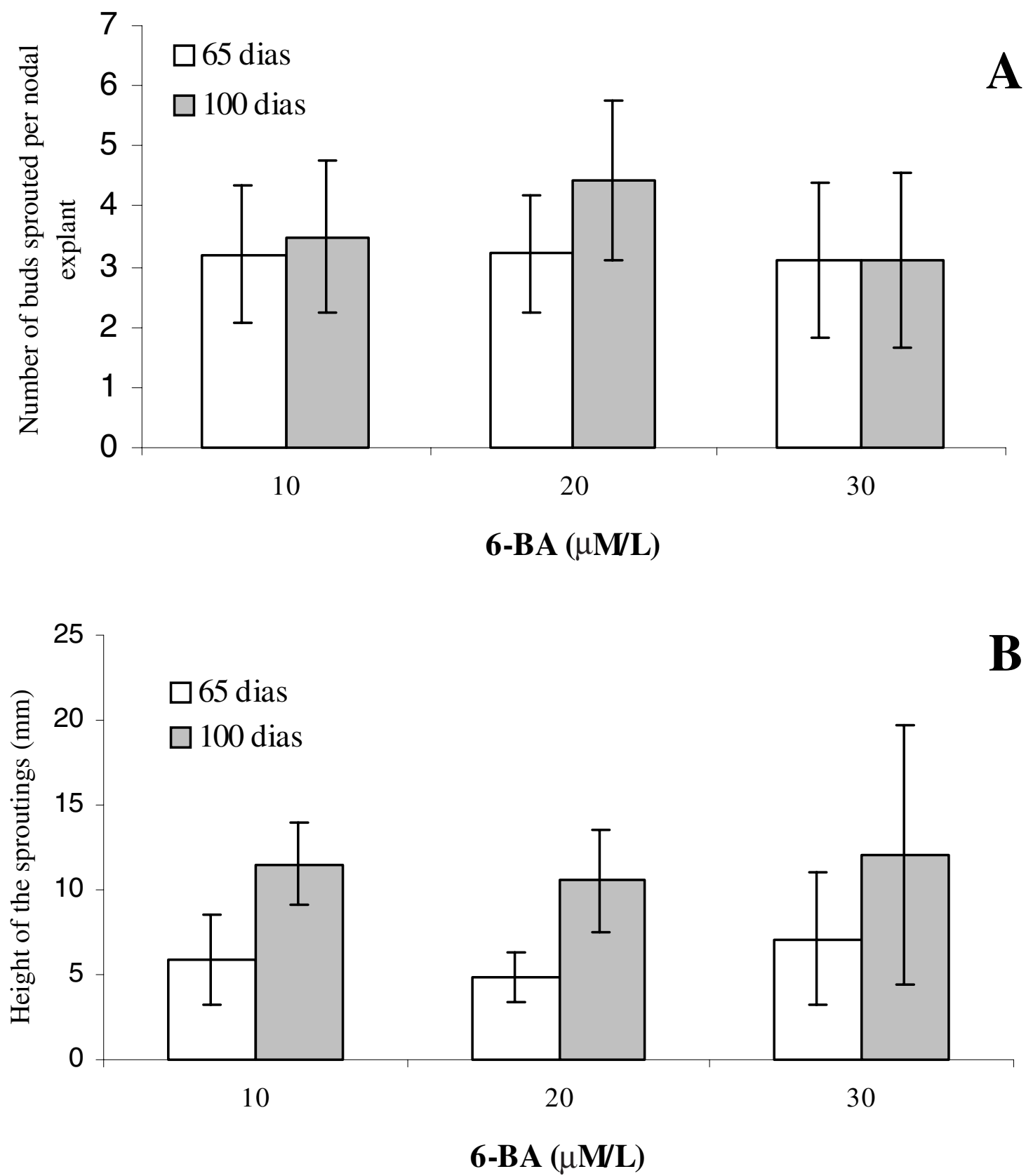

Figure 3. Effect of different concentrations of 6-BA on the number of buds sprouted per nodal explant (A) of Coffea arabica cv Mundo Novo, and on the height of the sproutings (B), 65 and 100 days after the inoculation. Vertical bars: standard errors. 


\section{Conclusion}

Data obtained in this study showed that the dose of $10 \mu \mathrm{M} \mathrm{L}^{-1}$ of 6-BA can be used to induce multiple sprouting on nodal explants of Coffea arabica $\mathrm{cv}$ Mundo Novo as those higher ones reported in the literature, like $88.8 \mu \mathrm{M} \mathrm{L}^{-1}$.

\section{References}

CUSTERS, J.B.M. Clonal propagation of Coffea arabica L. by nodal culture. In: COLLOQUE ASSOCIATION SCIENTIFIQUE INTERNATIONALE DU CAFÉ, 9, 1980, London. Proceedings ... Paris: ASIC, 1980. p.589-596.

DUBLIN, P. Multiplication vegetative in vitro de L'Arabusta. In: COLLOQUE ASSOCIATION SCIENTIFIQUE INTERNATIONALE DU CAFÉ, 9., 1980, London. Proceedings ... Paris: ASIC, 1980. p.571-588.

FORNI, R.C.; PASQUAL, M.; CARVALHO, G.R.; ICHIHARA, L.K. Níveis de sais do meio "MS" e de benzilaminopurina e seus efeitos na proliferação "in vitro" de gemas de café cv. Catuaí. In: CONGRESSO BRASILEIRO DE PESQUISA CAFEEIRA, 20, 1994, Guarapari. Resumos...Rio de Janeiro:MAARA/Pró-Café, 1994. p.12.

GANESH, D.S.; SREENATH, H.L. Clonal propagation of coffee through apical bud culture. Journal Plantation Crops, Karnataka, v.25, n.2, p.169-174, 1997.

GARCIA, E.G.; RAFAEL, M. Propagacion clonal de plantas de café (Coffea arabica L. "Catimor") a partir de microesquejes cultivados in vitro. Agronomia Tropical, Maracay, v.39, n.4-6, p.249-268, 1989.

GOUVEIA, N.M. Blüteninduktion bei Coffea arabica L. Der Tropenlandwirt, Zeitschrift für die Landwirtschaft in den Tropen und Subtropen, Jahrgang, v.88, p.139-143, 1987.

JESUS, A.M.S.; CARVALHO, S.P.; PASQUAL, M.;CARVALHO, M.; CORREAA, L.V.T. Efeitos de diferentes concentrações de BAP e dos meios básicos MS e WPM na proliferação e desenvolvimento de brotos axilares Coffea arabica in vitro In: SIMPÓSIO DE PESQUISAS DOS CAFÉS DO BRASIL, 3., 2003, Porto Seguro. Anais ... Brasília:Embrapa-Café, 2003. p.93.

JESUS, A.M.S.; CARVALHO, S.P.; PASQUAL, M.; CHAGAS, E.A.; CARVALHO, M.; DUTRA, L.F. Micropropagação do cafeeiro com concentrações de BAP em meio de pré-cultivo e de BAP e TDZ em meio de subcultivo. Revista Ceres, Viçosa, v. 49, n.283, p.253-263, 2002.
KAHIA, W.J. Plantlet regeneration from Coffea arabica shoot tips. Kenya Coffee, Nairobi, v. 58, n.675, p.1467-1471, 1993.

MCDANIEL, C.N. Competence, determination and induction in plant development. In: MALACINSKI, G.M.; BRYANT, S.V. (Eds.). Pattern formation a primer in developmental biology. New York: Macmillan Publishing, 1984. p.393-412.

MOORE, T.C. Biochemistry and physiology of plant hormones. New York:Spring-Verlag, 1979. p.330.

MURASHIGE, T.; SKOOG, F. A revised medium for rapid growth and bioassays with tobacco tissue cultures. Physiologia Plantarum, Copenhague, v.15, n.3, p.473-497, 1962.

NAKAMURA, T.; SONDHAL, M.R. Multiplicação in vitro de gemas ortotrópicas em Coffea spp. In: CONGRESSO BRASILEIRO DE PESQUISA DO CAFEEIRO, 9, 1981. São Lourenço. Resumos... Rio de Janeiro: IBC-GERCA, 1981. p.162-163.

NYANGE, N.E.; MCNICOL, R.J. High frequency induction and regeneration of multiple shoots from hypocotyl segments of Coffea arabica. In: COLLOQUE ASSOCIATION SCIENTIFIQUE INTERNATIONALE DU CAFÉ, 15, 1993, Montpellier. Proceedings... Paris: ASIC, 1993. p.738-740.

RIBEIRO, T.O.; CARNEIRO, M.F. Micropropagation by nodal culture of cultivars Caturra, Geisha and Catimor regenerated in vitro. In: COLLOQUE ASSOCIATION SCIENTIFIQUE INTERNATIONALE DU CAFÉ, 13, 1989, Paipa. Proceedings... Paris: ASIC, 1989. p.757-765.

SONDHAL, M.R. Coffee breeding assisted by somaclonal variation: the case of "Bourbon LC"' variety. In: COLLOQUE ASSOCIATIONSCIENTIFIQUE INTERNATIONALE DU CAFÉ, 19, 2001, Trieste. Proceedings ... Paris: ASIC, 2001. p B 210.

SONDHAL, M.R.; NAKAMURA, T.;SHARP, W.R. Propagation of coffee. In: HENKE, R.R.; HUGHES, K.W.; CONSTATIN, M.P.; HOLLAENDER, A. (Eds.). Tissue culture in forestry and agriculture. New York: Plenum Press, 1985. p.215-232.

TAMAS, I.A. Hormonal regulation of apical dominance. In: DAVIES, P.J. (Ed.). Plant hormones and their role in plant growth and development. Dordrecht: Martinus, 1987. p.393-410.

TURNBULL, C.G.N.; HAMKE, D.E. The control of bud dormancy in potato tubers. Planta, Berlin, v.165, p.359-365, 1985.

TREWAVAS, A. How do plant growth substances work? Plant Cell Environment, Utah, v.4, p.203-228, 1981.

WILLIAMS, E.G.; MAHESWARAN, G. Somatic embryogenesis: Factors influencing coordinated behavior of cells as an embryogenic group. Annals of Botany, Bristol, v.57, p.443462, 1986. 